\begin{tabular}{|c|c|c|}
\hline & Port-Said Engineering Research Journal \\
Faculty of Engineering - Port Said University
\end{tabular}

\title{
Mitigation of Lightning Overvoltages Using STATCOM in Grid-Connected PV Systems
}

\author{
Ibrahim Hamdeen, Mohammed A. Saeed, and Ebrahim A. Badran ${ }^{(1)}$
}

\begin{abstract}
-
Lightning strike causes a large lightning voltage injection into grid-connected PV systems at the point between inverter and transformer. The overvoltage resulting from the lightning-impulse voltage is a major concern for the multiple expensive electrical devices of the grid-connected PV system and to be studied in depth in order to decrease the damage caused by this overvoltage. In this paper, PSCAD/EMTDC software simulated the complete model of the system. In this work, the point which selected from gridconnected PV system to inject impulse lightning voltage is between transformer and inverter. In different locations of the gridconnected PV system, lightning overvoltage has been noted by injecting impulse lightning voltages. In this paper, the surge arrester is used to mitigate the lightning overvoltage on the PV array. STATCOM is used to improve voltage of the PV array. The results show that in case of using the surge arresters and STATCOM, the lightning overvoltage is mitigated.
\end{abstract}

Keywords-PV, Overvoltage, STATCOM, Surge Arrester, PSCAD

\section{Introduction}

Lightning is an electrical discharge of clouds in the atmosphere. It generates double-exponential impulses that have a significant impact on equipment and power systems. The resulting overcurrent or overvoltage propagates into the low voltage and the power lines [1].

Lightning overvoltage is separated into induced overvoltage and direct overvoltage. Induced overvoltage indicates the voltage produced by connecting lines to the electromagnetic field induced by the return current during the lightning return stroke period. While direct lightning overvoltage relates to the voltage produced by lightning currents that flow directly through electrical equipment, lines or houses when the lightning directly hits them [2].

The authors in [3] presented a lightning current with short tail time and high peak increases the transient voltage and current considerably. The lightning was injected between the inverter and the photovoltaic (PV). The transient current and voltage may travel along the conductor and damage other parts, especially the PV modules and inverters. They have given a references and instructions for installing lightning protection devices in solar photovoltaic farms. The effect of grounding system characteristics on the overvoltages in a grid-connected PV system caused by the lightning is analysed in [4]. The results proved that the frequency-dependency of soil parameters and the highfrequency grounding system behaviour can have a major impact on the resulting overvoltages compared to the simple grounding system resistive model.

\footnotetext{
${ }^{(1)}$ Electrical Engineering Department, Mansoura University, Mansoura, Egypt

ibrahim.hamdeen@yahoo.com,_mohammedsaid@mans.edu.eg, ebadran@mans.edu.eg
}

In [5], the lightning strike adds to high transient current and voltage, which can cause severe damage to electronic components and modules of the PV. Therefore, a suitable place of the surge protective device (SPD) was assigned to protect the inverter and modules of the PV. The results showed that, in addition to the inverter and modules of the solar array, the SPD should also be mounted to reduce the effect of the lightning strike.

In [6], the lightning strike induced a large transient current injection at the contact point into hybrid systems. The transient overvoltage induced by the lightning current is a major problem or the hybrid system's multiple expensive electrical equipment and needs to be researched in depth to minimize overvoltage damage. The result makes it essential for the engineers involved to choose SPDs with the most suitable levels for a specific point. The choice of SPD for a specific purpose depended on the level of threat and vulnerability of the component; the impulse to withstand voltage, waveform rise-time and maximum energy.

The authors in [7] presented invaded lightning overvoltage induced by the failure of the electrical apparatus to insulate. A monitoring system based on an arrester valve divider is performed to achieve the actual substation lightning invaded overvoltage. In [8] presented a temporary over voltage mitigation strategy for the grid-connected PV system. Single line to ground fault accompanied by insulation is a serious cause of temporary over-voltage. The result demonstrates that the neutral current is decreased to a certain degree by including high breaking current (HBC) in the circuit and that inverter power is reconnected to the grid after failure.

This paper presents a mitigation method for lightning overvoltage subjected to grid-connected PV system. The surge arresters and STATCOM are used to mitigate the 
resulting overvoltages. The study is carried out using PSCAD/EMTDC.

\section{TEST SYSTEM SIMULATION}

The PV module is a semiconductor device that transforms the radiation of solar directly to electrical energy. The modules are connected in parallel and in series to form a solar array with the required rated power. Fig. 1a illustrates a schematic diagram for grid-connected PV system [9]. The system contains PV source, a dc-link capacitor, a dc-dc converter, a dc-dc controller with maximum power point tracking (MPPT), a grid interface inverter with an appropriate filter and a step up transformer. Details of all parameters applied in the model for a PV cell are listed in Table 1.

\section{a) PV Grid-Connected System Simulation}

The 0.27 MW PV systems are simulated using PSCAD/EMTDC [9]. It mainly consists of as shown in Fig. 1b solar array, inverter, setup transformer and utility grid. The PV system is connected to the $11 \mathrm{kV}$ AC common bus; a $0.6 \mathrm{kV} / 11 \mathrm{kV}$ step-up transformer connects the AC common bus to the utility grid. The system operates at a frequency of $50 \mathrm{~Hz}$. The outputs of the PV grid-connected system are summarised in table 2 .

\section{b) The Impulse Lightning Voltage Simulation}

Lightning is an atmospheric electrical discharge, generally during thunderstorms. It is classified as intracloud, cloud-to-air, cloud to-cloud, and cloud-to-ground [3]. The lightning current and voltage can be characterised by the waveshapes through different mathematical expressions and the double exponential expression is used in this paper.

Referring to the IEEE standard, the proposed value for the lightning voltage and current impulses are $1.2 / 50 \mu$ s and $8 / 20 \mu$ s respectively [3]. Fig. 2 represents a standard impulse wave with $\mathrm{t} 1$ as front time and $\mathrm{t} 2$ as fall time. The standard specifications is $1.2 / 50 \mu$ s duration, Where front time is $1.2 \mu \mathrm{s}$ with a tolerance of $\pm 30 \%$ and a tail time of 50 $\mu$ s with a tolerance of $\pm 20 \%$ for a $1000 \mathrm{kV}$ peak value [5].

Marx generator [10] is the vital part of HV equipment's impulse voltage tests. Its output is a form of a double exponential function pulse:

$$
V(t)=V[\exp (-\alpha t)-\exp (-\beta t)]
$$

where $\mathrm{V}(\mathrm{t})$ is the instantaneous output voltage value and $\mathrm{V}$ is the voltage stored by the capacitor $(\mathrm{Cg}), \alpha$ and $\beta$ are inverse time constants in $\mu$ s.
Based on the Marx generator, the impulse generator is constructed. The Marx generator's main circuit is shown in Fig. 3a. As shown in Table 3, there is a typical $\mathrm{C} 1 / \mathrm{C} 2$ ratio for the special Marx generator circuit. $\mathrm{C} 1$ is a stage capacitor, C2 is a load capacitor, R1 is a front resistor and $\mathrm{R} 2$ is a tail resistor. The waveform depends on the $\mathrm{Rf}$ (front resistor) and Rt (tail resistor) by modifying the values of these resistors. These resistors control the output impulse voltage waveform wave-tail and wave-front [11].

The sphere gap for initiating the lightning is simulated using the switch to simulate the circuit using PSCAD / EMTDC, as shown in Fig. 3b. The function of the generator is also switched and all switches are simultaneously closed.

The stage capacitor, $\mathrm{C} 1$ is an initial charge value and is determined. The simulated circuit's output waveform is shown in fig. $3 \mathrm{c}$, with $1.2 \mu$ s rise time and $50 \mu$ s fall time.

TABLE 1: A PV CELL PARAMETERS [9]

\begin{tabular}{|c|c|}
\hline Items & Value \\
\hline Irradiation & $1000\left[\mathrm{~W} / \mathrm{m}^{2}\right]$ \\
\hline Temperature & $25\left[{ }^{\circ} \mathrm{C}\right]$ \\
\hline Series resistance of cell & $0.02[\Omega]$ \\
\hline Shunt resistance of cell & $1000[\Omega]$ \\
\hline Saturation current cell & $1 e-12[\mathrm{kA}]$ \\
\hline Short circuit current of cell & $0.0025[\mathrm{kA}]$ \\
\hline Coefficient of temperature & 0.001 \\
\hline
\end{tabular}

TABLE 2: OUTPUT OF PSCAD/EMTDC PV GRIDCONNECTED SYSTEM [9]

\begin{tabular}{|c|c|c|c|c|c|}
\hline \multicolumn{2}{|c|}{$\begin{array}{c}\text { Output of DC } \\
(\text { PV Array) }\end{array}$} & \multicolumn{4}{c|}{ Output of AC } \\
\cline { 3 - 6 } & \multicolumn{2}{|c|}{ Inverter } & \multicolumn{2}{c|}{ Transformer } \\
\hline $\begin{array}{c}\text { Vmax. } \\
(\mathrm{V})\end{array}$ & $\begin{array}{c}\text { Imax. } \\
(\mathrm{A})\end{array}$ & $\begin{array}{c}\text { Vmax. } \\
(\mathrm{kV})\end{array}$ & $\begin{array}{c}\text { Imax. } \\
(\mathrm{kA})\end{array}$ & $\begin{array}{c}\text { Vmax. } \\
(\mathrm{kV})\end{array}$ & $\begin{array}{c}\text { Imax. } \\
(\mathrm{kA})\end{array}$ \\
\hline 1500 & 185 & 0.6 & 0.4 & 11 & 0.023 \\
\hline
\end{tabular}

TABLE 3: DIFFERENT STANDARD WAVES LIMITING VALUES For $\mathrm{C} 1 / \mathrm{C} 2[10]$

\begin{tabular}{|c|c|c|c|c|}
\hline \multirow{2}{*}{ Value determined } & \multicolumn{4}{|c|}{$\mathrm{T}_{1} / \mathrm{T}_{2}(\mu \mathrm{S})$} \\
\cline { 2 - 5 } & $1.2 / 5$ & $1.2 / 50$ & $1.2 / 200$ & $250 / 2500$ \\
\hline Max. $(\mathrm{C} 1 / \mathrm{C} 2)$ & - & 40 & 185.19 & 6.37 \\
\hline
\end{tabular}

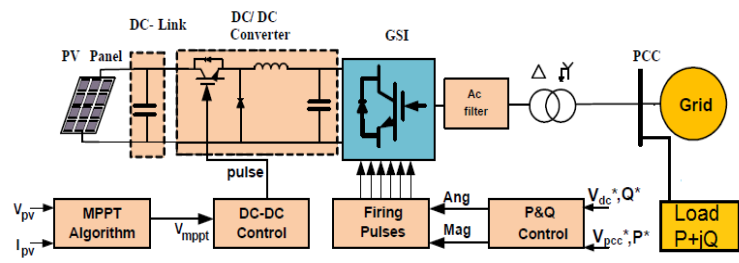

(a) The schematic diagram [9] 


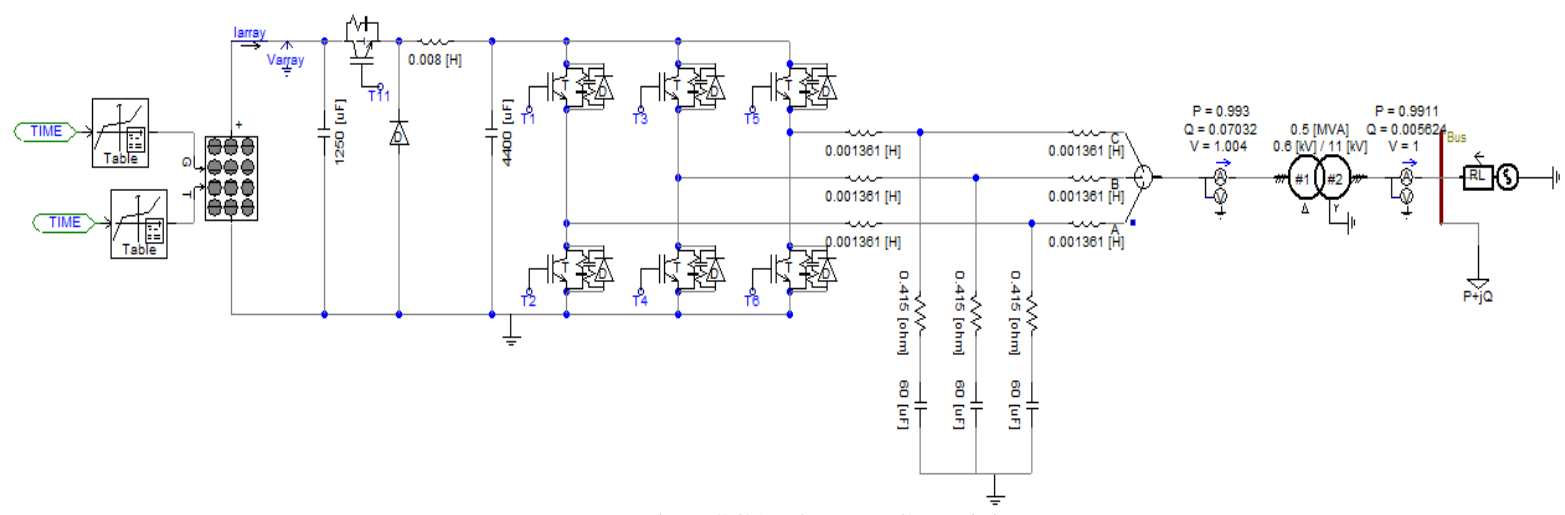

(b) The PSCAD/EMTDC model

Fig. 1: The Grid-connected PV system

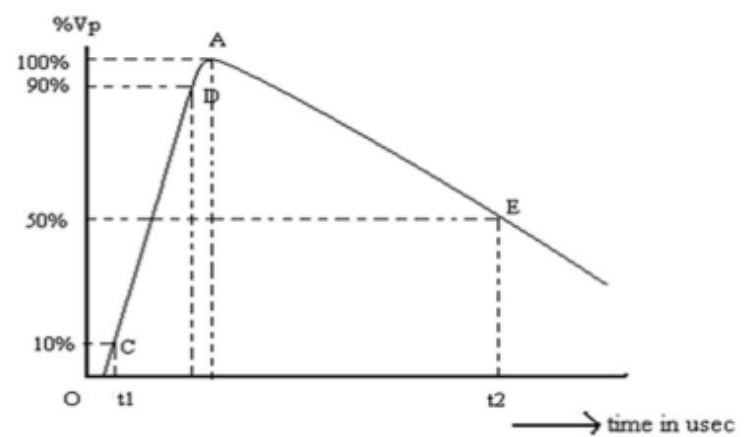

Fig. 2: Standard waveform of an impulse

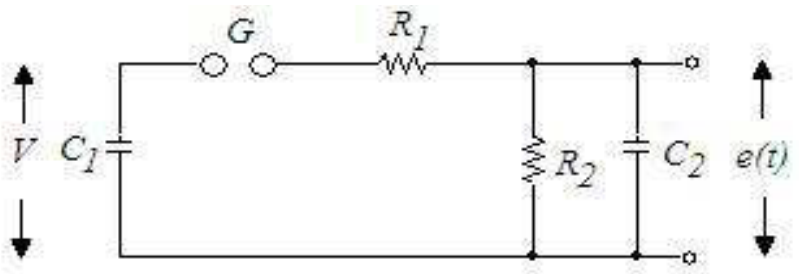

(a) Equivalent circuit

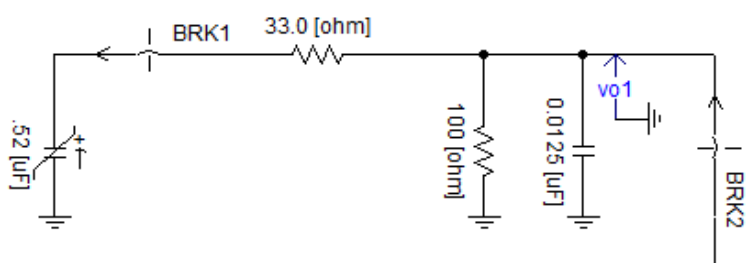

(b) PSCAD/EMTDC model

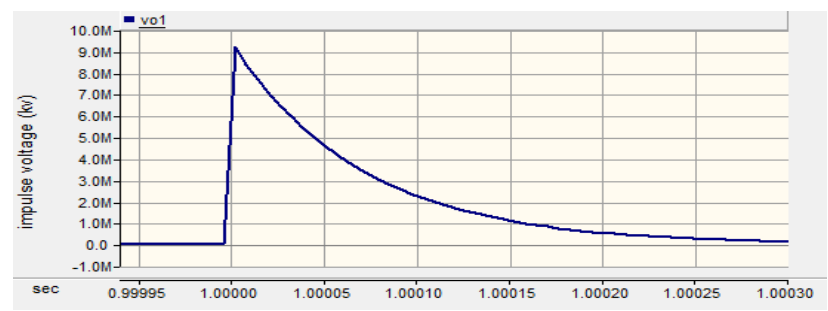

(c) The output of lightning impulse voltage.

Fig. 3: Impulse voltage generator

\section{LIGHTNING TRANSIENT OVERVOLTAGE IN PV GRID- CONNECTION SYSTEM}

Lightning impulse voltage hits the PV grid-connected system at inverter terminals. Fig. 3c illustrates the impulse lightning voltage $1.2 / 50 \mu$ s that hits the grid-connected PV system at $1 \mathrm{sec}$. The transient overvoltage appears at the PV array and point of common coupling (PCC).

Fig. 4a shows the PV array output voltage. It is raised up to $1.8 \mathrm{kV}$ at $1 \mathrm{sec}$ that it means the PV array is open circuit due to lightning impulse voltage. Fig. 4b shows the output current of the PV array. It is dipped to zero A at $1 \mathrm{sec}$ and the PV array is not operated due to protection limits.

Fig. 5 illustrates the active and reactive powers, the current, and the voltage at PCC when the impulse lightning voltage hits the grid-connected PV system at $1 \mathrm{sec}$. Fig. 5a shows the current at PCC. It is raised up to $4.5 \mathrm{MA}$ at $1 \mathrm{sec}$ and then it is decreased gradually to a steady state value of 23 A. Fig. 5b shows the voltage at PCC. It is raised up to $1.01 \mathrm{pu}$. Fig. $5 \mathrm{c}$ shows the active power at PCC. It is raised up to $2400 \mathrm{pu}$ at $1 \mathrm{sec}$ and then it is decreased gradually to 100 pu. Fig. $5 d$ shows the reactive power at PCC. It is raised up to $900 \mathrm{pu}$ at $1 \mathrm{sec}$ and then it is decreased gradually to $200 \mathrm{pu}$.

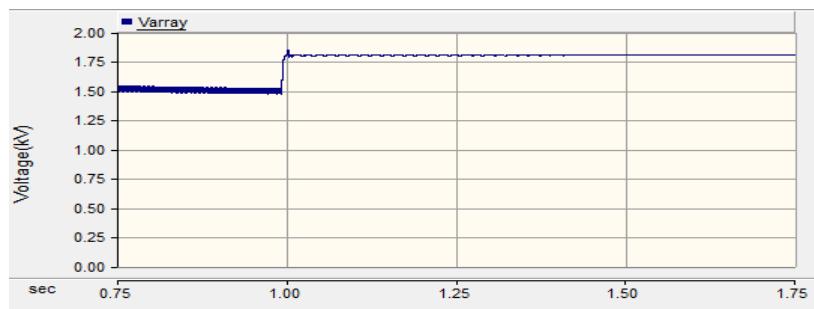

(a) Array voltage

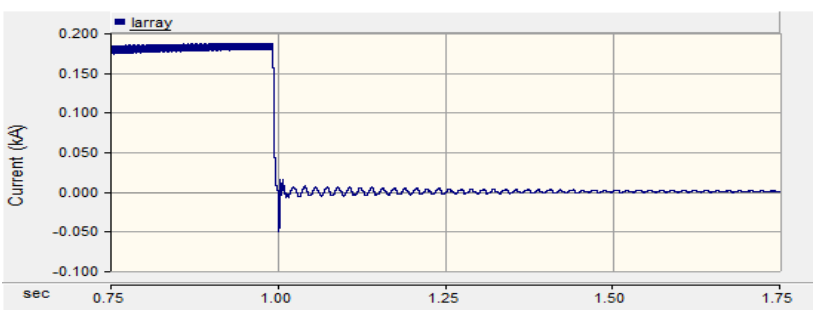

(b) Array current

Fig. 4: The Output of the PV array when a lightning impulse hits the system. 


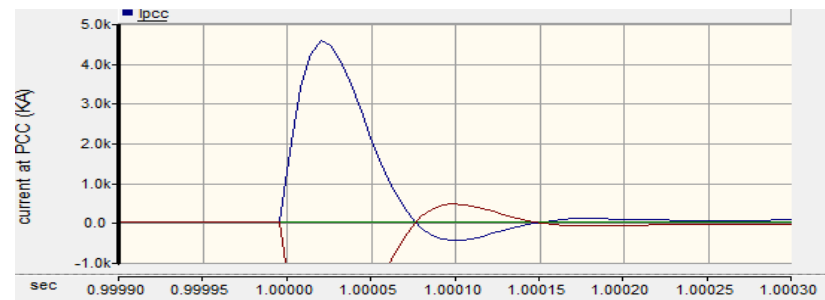

(a) current

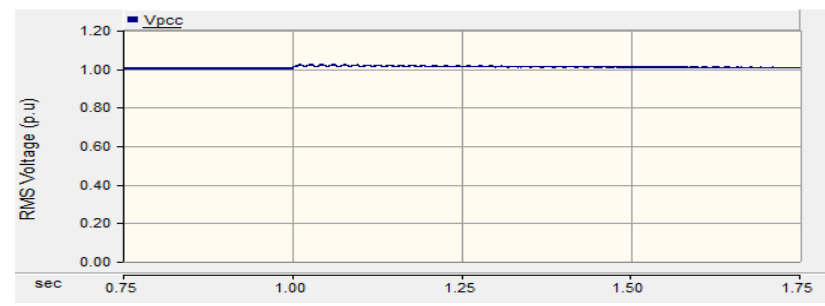

(b) Voltage

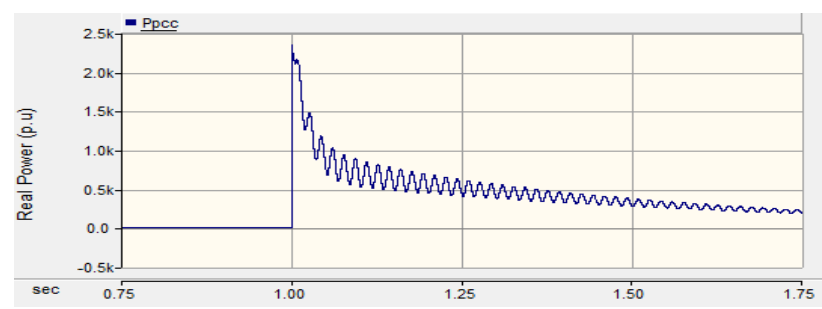

(c) Active power

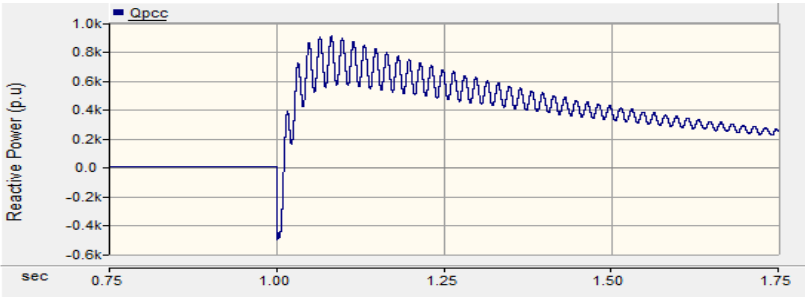

(d) Reactive power

Fig. 5: The output at PCC when a lightning impulse hits the system.

Fig. 6 illustrates the active and reactive powers, the current, and the voltage at inverter when the impulse lightning voltage hits the grid-connected PV system at 1 sec. Fig. 6a shows the current of the inverter. It is decreased to $70 \mathrm{MA}$ at $1 \mathrm{sec}$ and then it is raised up gradually to $10 \mathrm{MA}$, and then fluctuated at $1.5 \mathrm{MA}$. Fig. $6 \mathrm{~b}$ shows the voltage of the inverter. It is raised up to $4500 \mathrm{pu}$ at $1 \mathrm{sec}$ and then it is decreased gradually to a steady state value of $1 \mathrm{pu}$. Fig. 6c shows the active power of the inverter. It is dipped to $1.3 \times 10^{9} \mathrm{pu}$ at $1 \mathrm{sec}$ and then it is increased gradually to a steady state value of $1 \mathrm{pu}$. Fig. $6 \mathrm{~d}$ shows the reactive power of the inverter. It is raised up to $55 \times 10^{3} \mathrm{pu}$ at $1 \mathrm{sec}$ and then it is decreased gradually to $2 \times 10^{3} \mathrm{pu}$..

Fig. 7 illustrates the active and reactive powers, the current, and the voltage at grid when the impulse lightning voltage hits the grid-connected PV system at $1 \mathrm{sec}$. . Fig. 7a shows the voltage of the grid. It is $1 \mathrm{pu}$ and it is clearly seen that the voltage of the grid is not changed when the impulse lightning voltage hits the PV grid connected system. Fig. 7b shows the current of the grid. It is decreased to $-50 \mathrm{KA}$ and then increased gradually to $5 \mathrm{kA}$ and then fluctuated 250 . Fig. 7c shows the active power of the grid. It is dipped to $2400 \mathrm{pu}$ at $1 \mathrm{sec}$ and then it is increased gradually to -100 pu. Fig. $7 d$ shows the reactive power of the grid. It is decreased to $-900 \mathrm{pu}$ at $1 \mathrm{sec}$ and then it is increased gradually to $-180 \mathrm{pu}$.

Fig. 8 illustrates the active and reactive powers, the current, and the voltage at load when the impulse lightning voltage hits the grid-connected PV system at $1 \mathrm{sec}$. Fig. 8a shows the voltage of the load. It is raised up to $1.01 \mathrm{pu}$ at 1 sec.

Fig. 8b shows the current of the load. It is raised up to $0.25 \mathrm{kA}$ and then decreased $0.1 \mathrm{kA}$. Fig. $8 \mathrm{c}$ shows the active power of the load. It is raised up to $0.83 \mathrm{pu}$ at $1 \mathrm{sec}$ and fluctuated to a steady state value of 0.8 pu. Fig. $8 \mathrm{~d}$ shows the reactive power of load. It is fluctuated between $0.63 \mathrm{pu}$ and $0.8 \mathrm{pu}$.

Table 4 shows the comparison between the results at each point before and after lightning. It is clear that, the lightning overvoltage is occurred at the terminal of PV array, inverter, and PCC. Therefore, it is required to introduce a method for mitigation the resulting overvoltage due to impulse lightning voltage.

\section{Mitigation OF LightNing OVERVOLTAGE IN GRID- CONNECTED PV SYSTEM}

There are several methods to mitigate the overvoltage in the power system such as surge arrester, SPD, grounding system and STATCOM. Therefore, in this paper, the STATCOM and surge arrester are selected to mitigate the transient overvoltage due to the impulse lightning voltage that hits the grid-connected PV system.

\section{a) Mitigation Using Metal Oxide Surge Arrester}

Metal oxide varistor (MOV) [12 ] is used in advanced HV surge arresters worked with a highly nonlinear voltage compared to the current characteristic. The characteristic of the V-I depends on the current waveform of the arrester. The advanced physical building of HV arresters consists of MOV discs inside polymer insulator or porcelain. By adding discs in a sequence, high voltage is achieved. Using larger diameter discs or parallel disc shafts, the highest power ratings are obtained.

The IEEE model is shown in Fig. 9a [12]. A0 and A1 are the two nonlinear resistances separated by an RL filter. The front surges are slow, the RL filter has very little impedance and the model's nonlinear sections are essentially parallel. The front surge currents are fast, the impedance of a filter becomes more important, but in the non-linear A0 section the inductance $\mathrm{L} 1$ is more derived current. Since A1 has a reduced voltage for a given current than A0, a greater voltage is generated between its input terminals. Initially RLC elements are determined by the following formats [11, 12]:

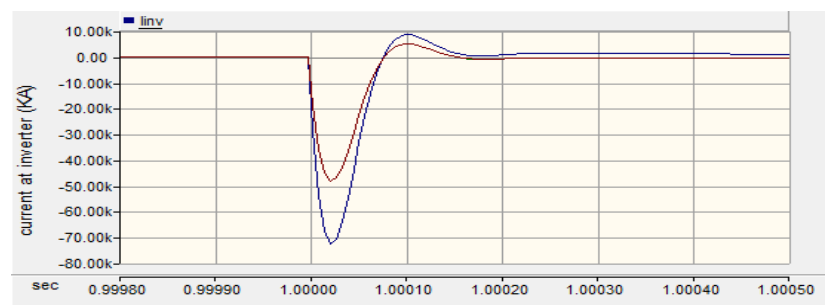

(a) Current 


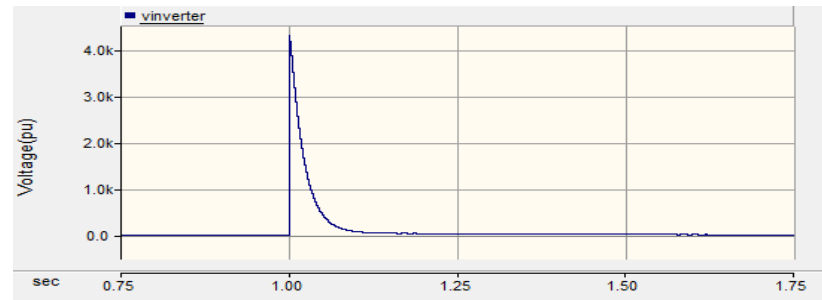

(b) Voltage

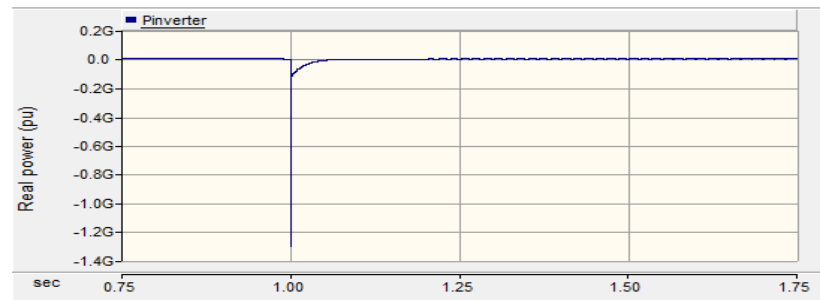

(c) Active power

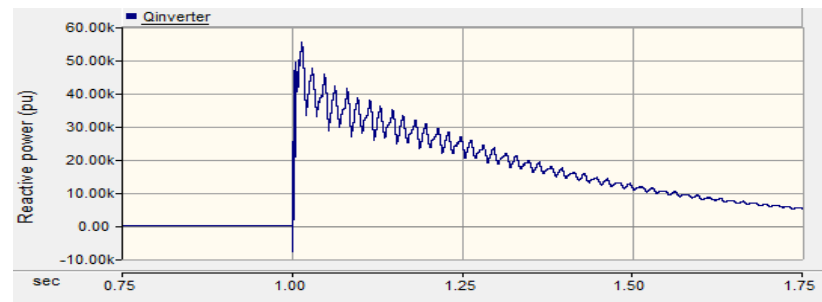

(d) Reactive power

Fig.6: The inverter output when a lightning impulse hits the system

TABLE 4: COMPARISON BETWEEN THE RESULTS AT EACH POINT BEFORE AND AFTER LIGHTNING

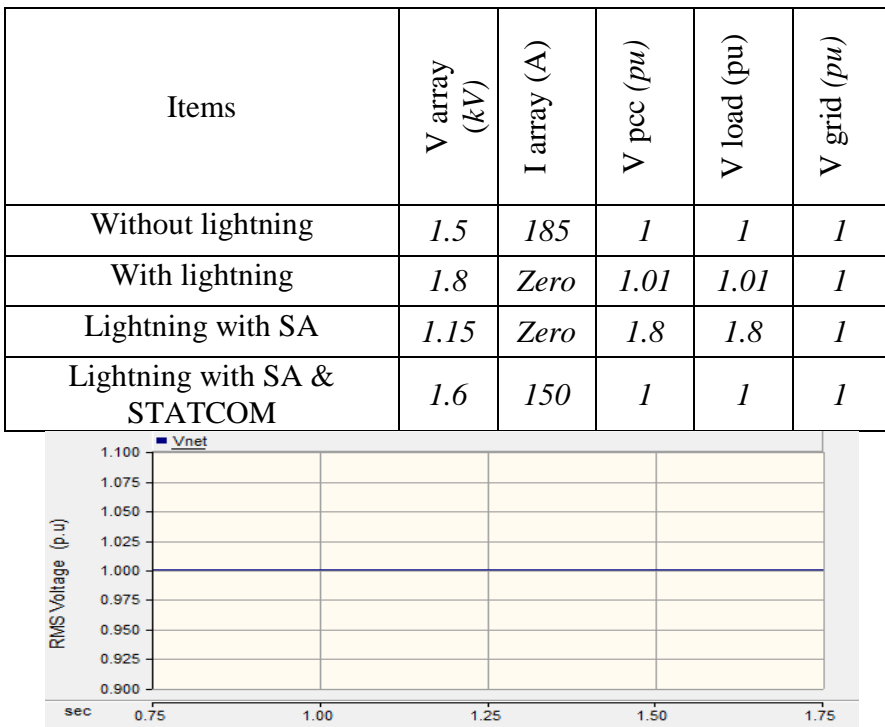

(a) Voltage

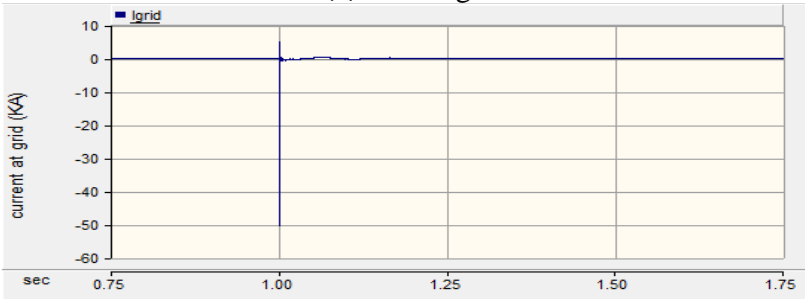

(b) Current

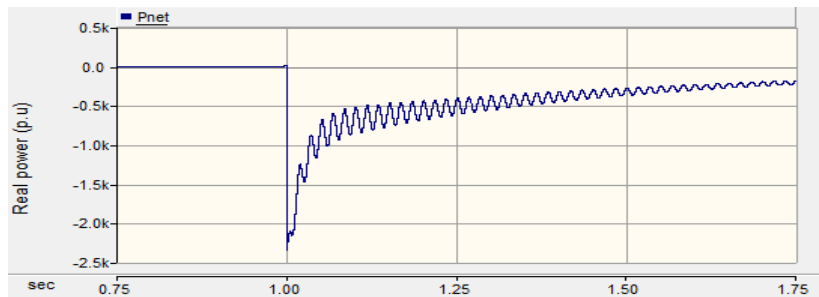

(c) Active power

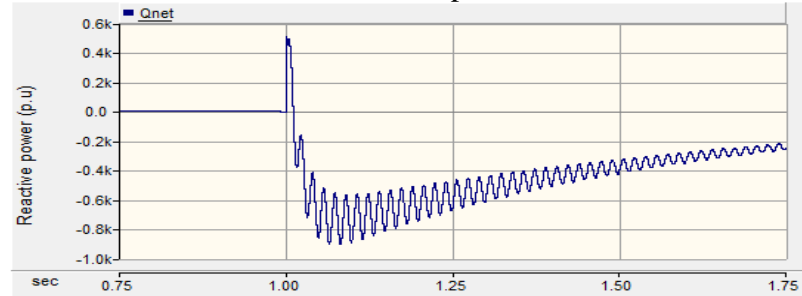

(d) Reactive power

Fig. 7: The output at grid when a lightning impulse hits the system

$\begin{array}{ll}L 1=15 d / n & \mu \mathrm{H} \\ R 1=65 d / n & \Omega \\ L 0=\frac{0.2 d}{n} & \mu \mathrm{H} \\ R 0=100 d / n & \Omega \\ C=100 n / d & \mathrm{pF}\end{array}$

where $d$ is the arrester's measured height in metres. $n$ is the number of metal oxide arrester parallel columns.

The model's inductance $L o$ is the inductance associated with magnetic fields in the arrester's immediate vicinity. When applying the model to the digital computer software, the $R o$ resistor is used for numerical integration stabilization. The capacitance $C$ represents arrester's the terminal-to-terminal capacitance of the arrester. The nonlinear V-I characteristics can be estimated $A O$ and $A I$ from the per unitized curves given in Fig. 9b. The metal oxide surge arresters is used on the two sides of the transformer with $\mathrm{d}=4 \mathrm{~m}$ and $\mathrm{n}=100$.

\section{b) Mitigation Using STATCOM.}

STATCOM is considered as a voltage-source converter (VSC) that uses a dc voltage to produce a three-phase ac voltage [9]. If the dc link voltage is increased, the reactive power flows from the inverter to the system and vice versa. The DC side of the STATCOM is used to keep the DC voltage as low as possible and to improve DC capacitor utilization [9]. The DC capacitor is used to inject reactive power to the STATCOM when the voltage is in sag condition. The parameters of STATCOM are calculated as equations in [9].

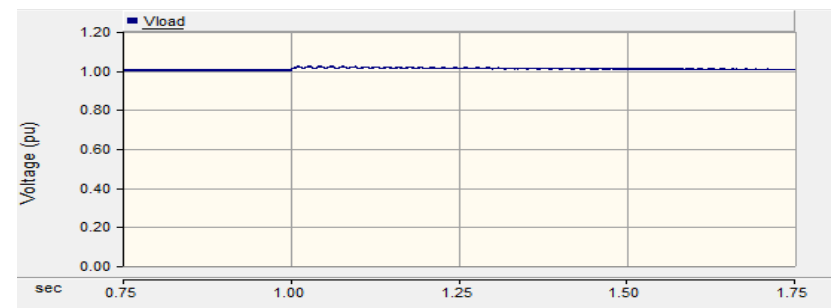

(a) Voltage 


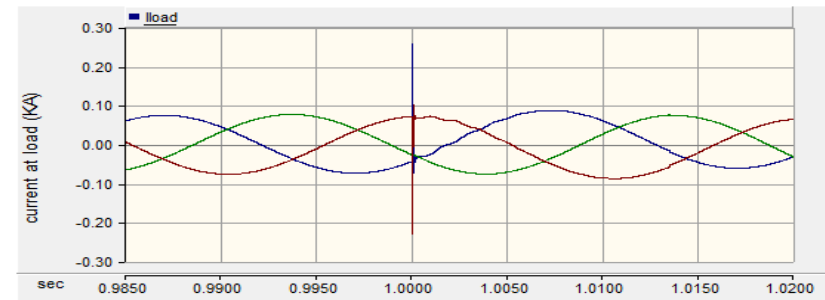

(b) Current

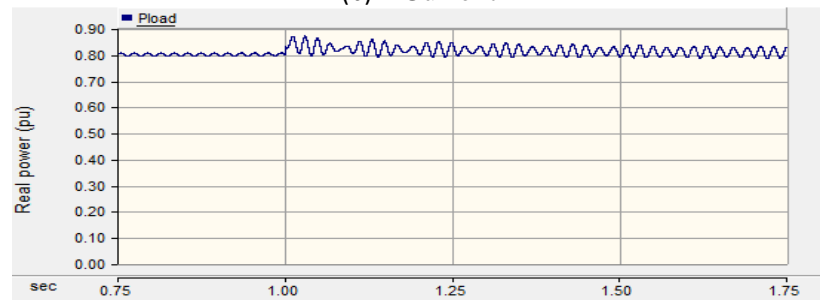

(c) Active power

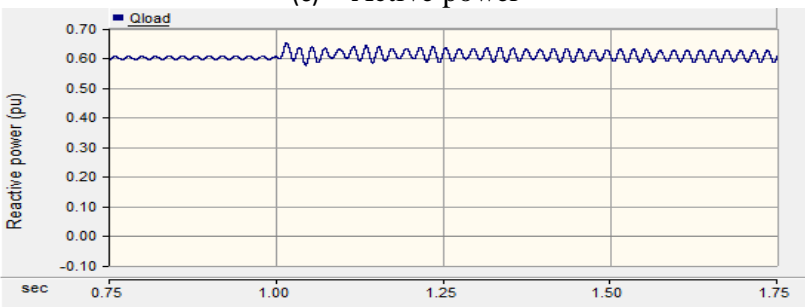

(d) Reactive power

Fig. 8: The output at load when a lightning impulse hits the system.

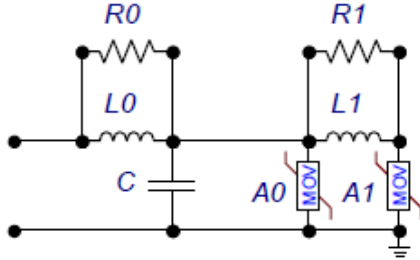

(a) IEEE Frequency-dependent model [12].

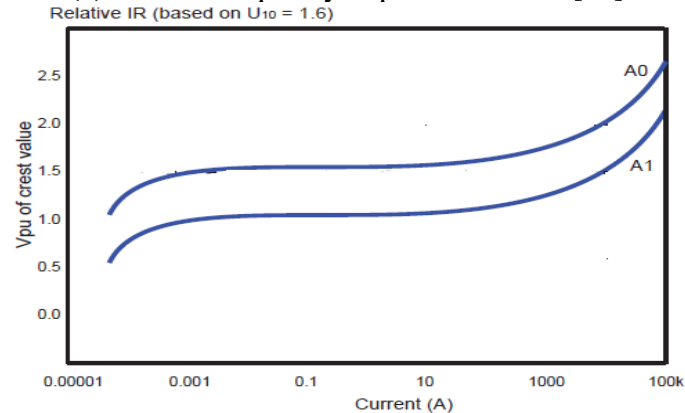

(b) V-I relationships [13].

Fig. 9: The metal oxide surge arrester

The dc bus voltage and power rating of STATCOM are given by [9]:

$$
\begin{array}{ll}
Q_{S T A T}=\sqrt{3} V I_{S} & \mathrm{KVar} \\
V_{D C}=\frac{2 \sqrt{2} V}{\sqrt{3} M_{a}} & \mathrm{~V}
\end{array}
$$

where $Q_{\text {STAT }}$ is the power rating of STATCOM, $V$ is the line voltage of STATCOM, $I_{S}$ is the STATCOM line current, $V_{\mathrm{DC}}$ is the dc bus voltage and $M_{a}$ is the modulation index of pulse width modulation.

The ac coupling inductor, $L_{A C}$, is calculated using the following form [9]:
$L_{A C}=\frac{\sqrt{3} M_{a} \cdot V_{D C}}{12 \cdot a \cdot f_{S} \cdot I_{P-P}}$

$\mathrm{mH}$

where $f_{\mathrm{S}}$ is the switching frequency, $I_{\mathrm{P}-\mathrm{P}}$, is the ripple current for ac inductor and $a$ is the overcurrent factor .

The dc bus capacitance of the STATCOM can be expressed as [9]:

$C_{D C}=\frac{3 V_{P h} I_{S} T}{\left(V_{D C}^{2}-V_{D C 1}^{2}\right)}$

$\mu \mathrm{F}$

where $T$ is the response time of STATCOM $(350 \mu \mathrm{s}), V_{\mathrm{DC} 1}$ is the dip in the dc bus voltage.

\section{RESUlts AND DISCUSSION}

In this paper, two mitigation methods are applied. Firstly, surge arresters are used when lightning is applied at $1 \mathrm{sec}$. Secondly, a STATCOM is added to the surge arresters when lightning is applied at $1 \mathrm{sec}$.

In first mitigation method, the surge arrester is used to mitigate the transient overvoltage on the PV array. Fig. 10a shows the output voltage of the PV array when the surge arresters are connected to the grid-connected PV system. The voltage decreases to $1.15 \mathrm{kV}$ at $1 \mathrm{sec}$ and then raises up gradually to $1.5 \mathrm{kV}$ that its steady state value. Also, Fig. 10b shows the output current of the PV array when the surge arresters are connected to the grid-connected PV system. It is dipped to zero A at $1 \mathrm{sec}$ and then raised up to the steady state value.

In second mitigation method, the surge arresters and STATCOM are used to mitigate the transient overvoltage on the PV array. Fig. 11a shows the output voltage of the PV array when the surge arresters and STATCOM are connected to the grid-connected PV system at $1 \mathrm{sec}$. The voltage is improved in this case than using surge arresters only and the PV array operates at steady state value. Fig. $11 \mathrm{~b}$ shows the output current of the PV array when the surge arresters and STATCOM are connected to the gridconnected PV system. It dips to $150 \mathrm{~A}$ and then raised up to the steady state value. It is better than using surge arresters only.

It can be seen that the surge arrester mitigates the lightning overvoltage of the PV array, but the output voltage of the PV array is minimized to $1.15 \mathrm{kV}$, the protection limits for this value is not satisfied and causes protection problems in the system. STATCOM is used in addition to the surge arrester to improve the voltage of the PV array. It is found that the lightning overvoltage of the PV array is mitigated and the PV array voltage is improved. Therefore, it is recommended to use surge arresters with STATCOM to improve the voltage of the PV array.

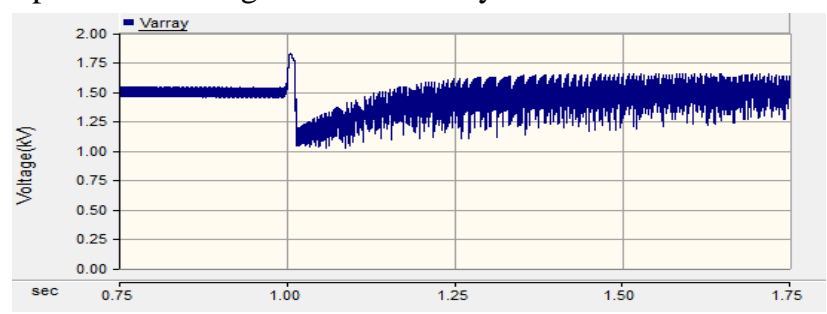

(a) Voltage 


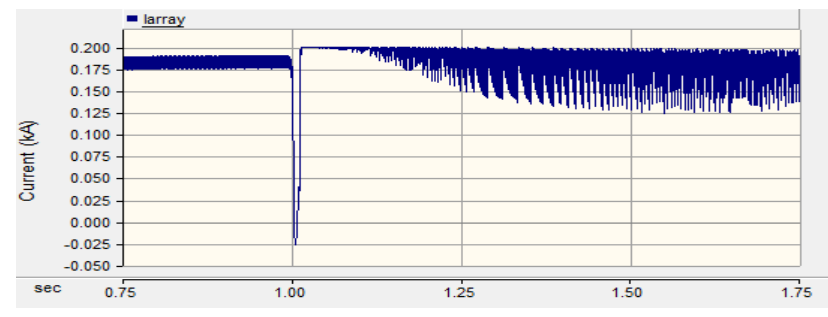

(b) Current

Fig. 10: The output of the PV array using surge arresters when lightning is applied at $1.0 \mathrm{sec}$.

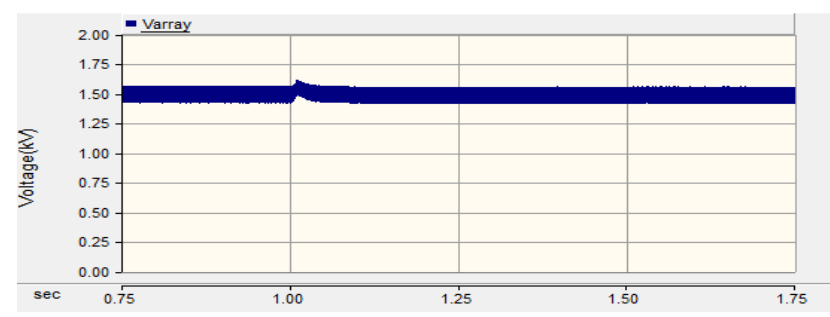

(a) Voltage

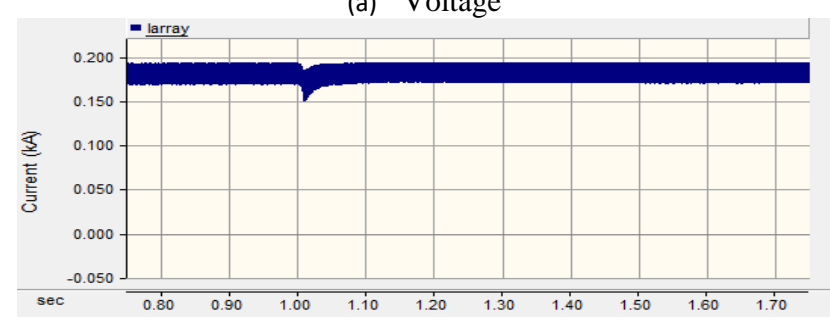

(b) Current

Fig. 11: The output of the PV array using surge arresters and STATCOM when lightning is applied at $1.0 \mathrm{sec}$.

\section{CONCLUSION}

In this paper, the lightning overvoltage waveforms that appear at different parts of the grid-connected PV system are investigated. The impulse lightning voltage is injected between transformer and inverter in the grid-connected PV system. In this paper, the metal oxide surge arrester is used to mitigate the lightning overvoltage on the PV array and with adding STATCOM. The results show that the overvoltage is mitigated to accepted limits and the voltage of the PV array is improved from $1.15 \mathrm{kV}$ to $1.5 \mathrm{kV}$.

\section{REFERENCES}

[1] L. Patidar, and H. Sawarkar, "Simulation of Impulse Voltage Testing of Power Transformers Using Pspice," International Journal Of Engineering Sciences \& Research Technology, Borawan Khargone, India, pp. 194-198, January 2015.

[2] S. Wang, S. Xie, Y. Ouyang, G. Liu, Y. Geng, H. Cai, C. Zhuang, R. Zeng and T. Li, "Analysis of LightningInduced Overvoltage Waveform Parameters," $34^{\text {th }}$ International Conference of Lightning Protection, Rzeszow, Poland, pp. 1-5, 02-07 September 2018.

[3] N. H. Zaini, M. Z. A. Ab. Kadir, M. A. M. Radzi, M. Izadi, N. Azis, N. I. Ahmed and M. S. M. Nasir, "Lightning Surge Analysis on a Large Scale GridConnected Solar Photovoltaic System," Energies, pp. 118, 15 December 2017.

[4] N. Ahmadi, V. Mashayekhi, S. H. H. Sadeghi and A. Nasiri, "Frequency-Dependent Modeling of Grounding System in EMTP for Lightning Transient Studies of Grid-Connected PV Systems," $4^{\text {th }}$ International
Conference on Renewable Energy Research and Applications, Palermo, Italy, pp. 989-993, 22-25 November 2015.

[5] N. H. Zaini, M. Z. A. Ab. Kadir, M. A. M. Radzi, M. Izadi, N. Azis, N. I. Ahmed and M. S. M. Nasir, "On the Effect of Surge Protection Devices (SPD) Placement for Grid-Connected Solar PV Farm," 34 ${ }^{\text {th }}$ International Conference of Lightning Protection, Rzeszow, Poland, pp. 1-5, 02-07 September 2018.

[6] Z. Mohammed, H. Hizam and C. Gomes, "Analsis of Lightning Transient Effects on Hybrid Renewable Energy Sources," $34^{\text {th }}$ International Conference of Lightning Protection, Rzeszow, Poland, pp. 1-7, 02-07 September 2018.

[7] J. Li, Y. Jiang, C. Zhang, Y. Zhang and X. Ma, "Substation lightning Invaded Over-voltage Monitoring System Based on Valve Divider," International Symposium on Lightning Protection (XIV SIPDA), Natal, Brazil, vol 5, issue 8, pp. 285-288, August 2016.

[8] S. S. Philip and D. E. Koshy, "Temporary Overvoltage Mitigation and Re-Connection of Inverter after Fault in a Grid-Connected Photovoltaic System," International Journal of Engineering Research and Technology, pp. 315-318, 02-06 October 2017.

[9] I. Hamdeen, M. A. Saeed and E. A. Badran, "Voltage Dip's Mitigation During PV-Grid-Connection Using STATCOM," $20^{\text {th }}$ International Middle East Power Systems Conference (MEPCON), Cairo University, Egypt, pp. 760-766, 18-20 December 2018.

[10] S. Kumar, N. K. Kishore and B. Hemalatha, "Parametric Analyses on Impulse Voltage Generator and Power Transformer Winding for Virtual High Voltage Laboratory Environment," $16^{\text {th }}$ National Power Systems Conference, Kharagpur, India, pp. 523-529, 15-17 December 2010.

[11] M. S. Kamarudin, E. Sulaiman, M. Z. Ahmed, S. A. Zulkifli and A. F. Othman, "Impulse Generator and Lightning Characteristics Simulation Using Orcad PSpice Software," $2^{\text {nd }}$ Engineering Conference on Sustainable Engineering Infrastructures Development and Management, Kuching, Sarawak, Malaysia, pp. 1032-1037, 18-19 December 2008`.

[12] P. UnahalekhakA, "Simplified Modeling of Metal Oxide Surge Arresters," 11th Eco-Energy and Materials Science and Engineering, Rajamangala University of Technology Suvarnabhumi, Thailand, pp. 92-101, 2014.

[13] Manitoba HVDC Research Center, "PSCAD/EMTDC Power System Simulation Software User's Manual," Version 4.5, 2012. 